\title{
Principles of Protection in Warfare under Islamic Law of War
}

\subsection{Introduction}

The aim of this chapter is to analyse - from a positivist perspective - the principles of protection, i.e. distinction and proportionality, under ILW. Although some extensive work has been undertaken by different scholars in the field with respect to the general evolution of ILW, ${ }^{1}$ the principles of protection have not been really examined in detail. The principles of distinction and proportionality (which are also found in the traditions of IHL, i.e. jus in bello) will be examined herein from the outlook of the primary sources of Islamic law, i.e. the Qur'an and the Sunnah. These primary sources provide the basis for understanding state conduct during peace and war times, i.e. the so-called siyar. $^{2}$ Without entering into the debate on the origins of IHL and ILW, ${ }^{3}$ this structure will facilitate an understanding of past and ongoing conflicts with perpetrators and victims from Islamic and Western origins. The chapter will firstly categorise the territorial and temporal jurisdiction of ILW, secondly its

1 For example:Muhammad Hamidullah, Muslim conduct of state(Sh. Muhammed Ashraf 1961); James Turner Johnson, The holy war idea in Western and Islamic traditions (Pennsylvania State University Press 1997); James Turner Johnson \& John Kelsay, Cross, crescent, and sword: the justification and limitation of war in Western and Islamic tradition (Greenwood Press 1990); Majid Khadduri, War and peace in the law of Islam (Johns Hopkins Press 1955); Rudolph Peters, Jihad in classical and modern Islam (Markus Wiener 1996); Niaz A. Shah, Islamic law and the law of armed conflict: the armed conflict in Pakistan (Routledge 2011).

2 Richard C. Martin, 'The religious foundations of war, peace, and statecraft in Islam', in James Turner Johnson \& John Kelsay (eds), Just war and jihad: historical and theoretical perspectives on war and peace in Western and Islamic traditions (Greenwood Press 1991), at 91. Siyar, however, is not strictly limited to these primary sources but include others like arbitral awards, orders of commanders, treaties, etc. The latter are also often based on the Qur'an and the Sunnah.

3 See Karima Bennoune, “'As-Salamu Alaykum” humanitarian law in Islamic jurisprudence', (1993-1994) 15 Michigan Journal of International Law, 605; Carolyn Evans, 'The double-edged sword: religious influences on international humanitarian law', (2005) 6 Melbourne Journal of International Law, 1. 
subjects, and finally the conduct of hostilities in order to give a clearer picture of certain principles present within the Qur'anic experience but whose juristic interpretations have blurred the straightforwardness by which the Prophet Muhammad had spread the message of Islam. This latter historical context will be dealt with in Part II (Chapter IV), where a closer look at the narratives of the Islamic Self and its Other will try to expose how-over time-such divisions seem to have influenced the law to reflect such discourse.

Before dealing with the substantive issues in this chapter, a closer look upon the sources of Islamic law is mandatory. Traditionally, the sources of Islamic law are categorised into the Qur'an, the Sunnah, ijma (consensus among the jurists) and qiyas (analogy). However, not all madhahib agree upon the latter two sources and rather treat them as methodologies to interpret the primary divine sources of Islamic law, i.e. the Qur'an and the Sunnah which override all the other sources of Islamic law. The Qur'an constitutes of the Revelation to the Prophet Muhammad. Very few verses in the Qur'an refer to fighting. Therefore, the need to analyse the Sunnah which constitutes of the Traditions of the Prophet Muhammad, namely the things He has done, said and acquiesced to during His lifetime. These Traditions have been transmitted through the hadiths which are collections of those Traditions. Their credibility and authenticity depend on the chain of narration and the people involved in collecting these Traditions. ${ }^{4}$ For those reasons, we will use the collection of hadiths from Al-Bukhari (d. 870), called the Sahih ${ }^{5}$ which, generally, has been accepted by jurists as being of high authenticity. ${ }^{6}$

\section{Territorial and Temporal Jurisdiction}

\subsubsection{On War and Peace}

Before analysing ILW and its jurisdictional regimes, its historical development will be briefly dealt with. ILW has been formulated by the jurists in terms of historical progress made by the Islamic community, i.e. the ummah, from the

4 Wael B. Hallaq, An introduction to Islamic law (Cambridge University Press 2009), at 16-9; Arif Ali Khan \& M.H. Syed, Concept of Islamic law (Pentagon Press 2007), at 6o-1.

5 See M. Muhsin Khan, Translation of Sahih Bukhari, at http://www.iiu.edu.my/deed/hadith/ bukhari/index.html. (Last accessed 15 February 2015)

6 Jonathan A.C. Brown, Hadith: Muhammad's legacy in the medieval and modern world (Oneworld Publications 2009), at 7 and 39. 
period of Revelation onwards ${ }^{7}$ through the early battles of Islam. ${ }^{8}$ The establishment of the first Islamic community was accompanied and guided by the Revelation to the Prophet and the teachings of the Prophet. The Qur'an and the Traditions would adapt to the challenges which the first Muslims were facing both from within and outside their community. ${ }^{9}$ In the first instance, the Islamic faith had to be propagated peacefully. Until the Meccans continued to persecute the Muslims in Medina after their migration there, the ummah needed to be defended accordingly against their aggressive enemies. The moment the new Muslim state gained more power, it could afford to pursue an offensive policy in the Arabian Peninsula rather than a defensive one. ${ }^{10}$ After the victories of the Islamic armies within this territory, an expansionist desire would spread the message around the rest of the world ${ }^{11}$ with the aim of inviting the non-Muslims to embrace this new religion or otherwise subject them to the Islamic rule while permitting them to continue their own religious practices..$^{12}$ In that regard, the so-called "peace verses"13 though they precede those of the "sword", were set aside. ${ }^{14}$ Hence, the theory of abrogation, i.e. $n a s k h{ }^{15}$ was particularly useful for setting aside the initial engagement of

7 Ann Elizabeth Mayer, 'War and peace in the Islamic tradition and international law', in James Turner Johnson \& John Kelsay (eds), Just war and jihad: historical and theoretical perspectives on war and peace in Western and Islamic traditions (Greenwood Press 1991), at 197 .

8 Towqueer Alam Falahi, The Quranic concept of war and peace (Kanishka Publishers 2004), at 90-101.

9 Mayer, in, at 197 .

10 Abdullahi Ahmed An-Na'im, Toward an Islamic reformation: civil liberties, human rights, and international law (Syracuse University Press 1996), at $15^{8}$.

11 Bernard K. Freamon, 'Martyrdom, suicide, and the Islamic law of war: a short legal history', (2003-2004) 27 Fordham International Law Journal, 299, at 314-15.

12 Wael B. Hallaq, Shari'a: theory, practice, transformations (Cambridge University Press 2009), at 327 .

13 While the "peace verses" are indicative of the message of peace which the Revelation stands for, the "sword verses" on the other hand, which were revealed after the peace ones, are rather interpreted to justify a continuous warfare with the unbelievers. See Sohail H. Hashmi, 'Interpreting the Islamic ethics of war and peace', in Sohail H. Hashmi (ed), Islamic political ethics: civil society, pluralism, and conflict (Princeton University Press 2002), at 206.

14 See David Bukay, 'Peace or jihad? Abrogation in Islam', (2007) 14 Middle East Quarterly, 3.

15 As an interpretive technique, the theory of abrogation justifies to repeal particular Quran'ic verses by others based upon the assertion that some verses are contradicting each other and that clarity needs to be achieved when reading the Qur'an by giving preference to only one side of the conflicting verses. Here, the "sword verses" have benefited 
peaceful understanding with the non-Muslim communities and affirming the waging of war with them instead. ${ }^{16}$ For example, the "peace verse" in Q8:61 "But if the enemy incline towards peace, do thou (also) incline towards peace, and trust in Allah. For He is One that heareth and knoweth (all things)" was considered by early Islamic jurists to have been abrogated. Thus, by virtue of the theory of abrogation the "peace verse" was replaced by the later "sword verse" in Q9:29 "Fight those who believe not in Allah nor the Last Day, nor hold that forbidden which hath been forbidden by Allah and His Messenger, nor acknowledge the religion of Truth, (even if they are) of the People of the Book, until they pay the Jizya with willing submission, and feel themselves subdued"17 Kamali has argued that the use of the theory of abrogation by early Islamic jurists to sweepingly supersede the "peace verses" with the "sword verses" was influenced "by the prevailing pattern of hostile relations with non-Muslims" at the time. ${ }^{18}$ Clearly, such interpretations set aside the defensive wars which would preserve the ummah for the sake of an aggressive jihad which became legally justified by the jurists as being the normal and universal condition of the Islamic state's relations with its rivals ${ }^{19}$ at that particular time in history. ${ }^{20}$

The earliest codified sources on siyar-i.e. the law on the conduct and behaviour of the Islamic state in peace and war times ${ }^{21}$ —already dated from

from such abrogation at the expense of the "peace verses". See John Burton, The sources of Islamic law: Islamic theories of abrogation (Edinburgh University Press 1990).

16 Hashmi, in, at 206.

17 This research is using the translation of the Holy Qur'an by Yusuf Ali. See Yusuf Ali, The Holy Quran, at http://www.harunyahya.com/Quran_translation/Quran_translation_ index.php. (Last accessed 8 March 2012) Any citation to the Qur'anic verses are made to the above mentioned translation and will be implied from now onwards as a reference work.

18 Muhammad H. Kamali, Principles of Islamic jurisprudence (The Islamic Texts Society 2003), at 223.

19 Mohammad Tal'at al-Ghunaimi, The Muslim conception of international law and the Western approach (Martinus Nijhoff Publishers 1968), at 137; Hashmi, in, at 205; Hilmar Krüger, Fetwa und Siyar: zur internationalrechtlichen Gutachtenpraxis der osmanischen Seyh ül-Islâm vom 17. bis 19. Jahrhundert unter besonderer Berücksichtigung des "Behcet ül-Fetâvâ" (Harrassowitz 1978), at 119; Abdul Hamid Ahmad Abu Sulayman, Towards an Islamic theory of international relations: new directions for methodology and thought (1993) (Revision of a thesis (PhD), International Institute of Islamic Thought, University of Pennsylvania, 1973), at 43 .

20 Mashood A. Baderin, 'The evolution of Islamic law of nations and the modern international order: universal peace through mutuality and co-operation', (2000) 17 American Journal of Islamic Social Sciences, 57, at 67 .

21 Hamidullah, at 10. 
$1240 .{ }^{22}$ They dealt inter alia with non-Muslim subjects within-i.e. in the dar al-Islam (the abode of Islam, outside Muslim territory, i.e. in the dar al-harb (the abode of war)), and with treaty partners, i.e. in the dar al-sulh (the abode of the covenant). ${ }^{23}$ These territorial divisions, from the offensive jihad perspective, were functionally only temporary as they would seize to exist when all peoples belonged to the same Muslim state through imperial jihadist and annexation policies. ${ }^{24}$ These aggressive policies were presented as being part of a religious obligation. ${ }^{25}$ According to Khadduri, it was a permanent struggle until the dar al-harb was overcome by the dar al-Islam not only militarily and politically but also psychologically. ${ }^{26}$ Nonetheless, a number of political practices in Islamic history could be given that would prove the contrary ${ }^{27}$ as they conflict with the values of peace and justice which Islam stands for. ${ }^{28}$ Regardless of the hostile environment of tribal warfare in the Arabian Peninsula ${ }^{29}$ and where threatening empires and their ideologies in their turn could have overrun their newly emerging Islamic competitor, ${ }^{30}$ the categorisations of non-Muslim peoples in opposition to the $u_{m m a h}{ }^{31}$ would approve the use of force ${ }^{32}$ against the nonMuslims in order to dominate and rule against them in future hostile situations. If one advocates peaceful coexistence among peoples where sovereignty is to be respected, war can only be of a defensive nature..$^{33}$

22 Khaled Abou El Fadl, Rebellion and violence in Islamic law (Cambridge University Press 2001), at 144 .

23 Abu Sulayman, at 7 .

24 Khadduri, at 44; Isam Kamel Salem, Islam und Völkerrecht: das Völkerrecht in der islamischen Weltanschauung (Express Edition 1984), at 98.

25 Mayer, in, at 202.

26 Majid Khadduri, The Islamic law of nations: Shaybani's Siyar (John Hopkins Press 1966), at 16-7; Maulana Muhammad Ali, A manual of hadith (Curzon Press 1988), at 252.

27 Baderin, at 59.

28 See also Niaz A. Shah, Self-defense in Islamic and international law: assessing Al-Qaeda and the invasion in Iraq (Palgrave Macmillan 2008), at 31.

29 An-Na'im, at 142.

$30 \quad$ Baderin, at 67 .

31 Syed Riazul Hassan, The reconstruction of legal thought in Islam: a comparative study of the Islamic and the Western systems of law in the latter's terminology with particular reference to the Islamic laws suspended by the British rule in the sub-continent (Law Publishing Company 1974), at 136.

32 An-Na'im, at 142.

33 Id., at 153; al-Ghunaimi, at 180; Majid Khadduri, 'The Islamic theory of international relations and its contemporary relevance', in J. Harris Proctor (ed), Islam and international relations (Pall Mall 1965), at 31 . 
Evidently, this "territorial demarcation" should also be seen in the light of "the war-prone tendencies of those times", 34 as Baderin argues. Consequently, siyar kept its importance to regulate this state of affairs and appeared to have become part of the eternal problem. ${ }^{35}$ Such man-made corpus of Islamic law of nations resulting from the juristic efforts of different schools of law ${ }^{36}$ has been misappropriated in reality and started to live its own life. Theoretically, states which are not in factual war with the Muslim state would be at war anyhow. ${ }^{37}$ The bifurcation of the world order into different spheres was a legal fiction ${ }^{38}$ having no textual support whatsoever in the primary sources. ${ }^{39}$ These divisions were developed by the jurists as the "ex post facto legitimation of the early conquests" ${ }^{20}$ from the eighth century onwards. ${ }^{41}$ In this regard, peace could no longer be considered to be an interval of recess ${ }^{42}$ and war would be a transitory condition. ${ }^{43}$ The Qur'an however demands the Muslims not to be aggressors in any case; they shall only fight for the cause of God against the injustices inflicted upon Muslims, ${ }^{44}$ namely to repel aggression, to protect the historic mission of Islam and to defend religious freedom. Fights for such cause as opposed to those fights for worldly political reasons are the only fights which are sanctioned religiously. ${ }^{45}$ Or in the words of the Prophet: "He who

\section{Baderin, at $67-8$.}

35 Majid Khadduri \& Herbert J. Liebesny, Law in the Middle East / Vol. 1, Origin and development of Islamic law (Middle East Institute 1955), at $35^{0 .}$

36 Gamal M. Badr, 'A survey of Islamic international law', (1982) 76 American Society of International Law Proceedings, 56, at 56 .

37 al-Ghunaimi, at 183-84.

38 Hashmi, in, at 207.

39 Niaz A. Shah, 'Self-defence in Islamic law', (2005-2006) 12 Yearbook of Islamic and Middle Eastern Law, 181, at 193 .

40 Abdulaziz A. Sachedina, 'The development of jihad in Islamic revelation and history', in James Turner Johnson \& John Kelsay (eds), Cross, crescent, and sword: the justification and limitation of war in Western and Islamic tradition (Greenwood Press 1990), at 37.

41 Fred M. Donner, 'The sources of Islamic conceptions of war', in James Turner Johnson \& John Kelsay (eds), Just war and jihad: historical and theoretical perspectives on war and peace in Western and Islamic traditions (Greenwood Press 1991), at 50.

42 Khadduri \& Liebesny, Law in the Middle East / Vol. 1, Origin and development of Islamic law, at 354 .

43 Abu Sulayman, at 121-22.

44 Bassam Tibi, 'War and peace in Islam', in Sohail H. Hashmi (ed), Islamic political ethics: civil society, pluralism, and conflict (Princeton University Press 2002), at 178.

45 Abou El Fadl, at 63; Rudolph Peters, Jihad in medieval and modern Islam: the chapter on jihad from Averroes' legal handbook "Bidayat al-mudjtahid" and the treatise "Koran and fighting" by the late Shaykh al-Azhar Mahmud Shaltut (E.J. Brill 1977), at 55 and 85 . 
fights that Allah's Word (i.e. Islam) should be superior, fights in God's cause."46 Therefore, only an aggression, i.e. a first attack, ${ }^{47}$ against the Islamic community necessitates the collective response or obligation (as seen by the Sunni schools of law, i.e. Hanafi, Hanbali, Maliki and Shafi $)^{48}$ of the Muslims defending ${ }^{49}$ their so-called "Islamic world order" 50 and its "doctrine of monotheism". ${ }^{11}$ First aggressive armed attacks by Muslims are prohibited and constitute a provocation and thus a transgression as illustrated in different verses of the Qur'an: ${ }^{22}$

Fight in the cause of Allah those who fight you, but do not transgress limits; for Allah loveth not transgressors. (Q2:190)

And fight the Pagans all together as they fight you all together. But know that Allah is with those who restrain themselves. (Q9:36)

And fight them on until there is no more Tumult or oppression, and there prevail justice and faith in Allah. But if they cease, let there be no hostility except to those who practise oppression. (Q2:193)

Allah forbids you not, with regard to those who fight you not for (your) Faith nor drive you out of your homes, from dealing kindly and justly with them: for Allah loveth those who are just. (Q6o:8)

Allah only forbids you, with regard to those who fight you for (your) Faith, and drive you out of your homes, and support (others) in driving you out, from turning to them (for friendship and protection). It is such as turn to them (in these circumstances), that do wrong. (Q60:9)

46 Al-Bukhari, Vol. 4, Book 52, Number 65. (Narrated by Abu Musa)

47 Ali, A manual of hadith, at 265.

48 al-Ghunaimi, at 141; S. Mahmassani, Les principes du droit international à la lumière de la doctrine islamique (Recueil des Cours. Académie de Droit International 1966), at 281.

49 M. Raquibuz Zaman, 'Islamic perspectives on territorial boundaries and autonomy', in Sohail H. Hashmi (ed), Islamic political ethics: civil society, pluralism, and conflict (Princeton University Press 2002), at 95.

5o Sachedina, in, at 36 .

51 Peters, Jihad in medieval and modern Islam: the chapter on jihad from Averroes' legal handbook "Bidayat al-mudjtahid" and the treatise "Koran and fighting" by the late Shaykh al-Azhar Mahmud Shaltut, at 43.

52 al-Ghunaimi, at 167; Ali ibn Muhammad Mawardi \& Asadullah Yate, al-Ahkam asSultaniyyah: the laws of Islamic governance (Ta-Ha Publishers 1996), at 63; Peters, Jihad in classical and modern Islam, at 74 . 
It may be that Allah will grant love (and friendship) between you and those whom ye (now) hold as enemies. For Allah has power (over all things). And Allah is Oft-Forgiving, Most Merciful. (Q60:7)

The classical Islamic jurists institutionalised the dichotomy between the good and the evil in their respective abodes of peace and war. Jihad, initially the fight against aggression, has later become the instrument not "in the fulfilment of the divine promise",53 as understood by Sachedina, but rather the strategy to gain political control over its Muslim and non-Muslim adversaries. A universal Islam ${ }^{54}$ with peaceful coexistence among peoples and religions ${ }^{55}$ on equal footing ${ }^{56}$ would be set aside by political ambitions for power. The consolidation of universal Islam whose extinction by its enemies has been feared by the Islamic establishment could possibly explain the violations of ILW towards Islam's Others. ${ }^{57}$ As a result, such division has appropriated and reproduced itself within the realities in which Muslims had to interact with their internal and external enemies. This early juristic polity and its legally instituted fiction of division of the world and its subjects will be object of the rest of this study. It will constitute the benchmark against which the Qur'anic experience and the Sunnah needs to be reflected. These man-made elucidations contrast with the Qur'an which explains the diversity of humanity in religious terms not in military-political territorialities. Against this brief historical background on the relationship between war and peace in Islam, we will now examine how this relationship is also translated into legal terms and in particular what the territorial and temporal jurisdictional scopes of ILW are.

\subsubsection{During External Warfare}

1.2.2.1 Territorial Jurisdiction

A territory becomes part of the abode of war and jihad has to be waged, as al-Ghunaimi states, whenever "Muslim rule and directions are not applied

53 Sachedina, in, at $36-7$.

54 al-Ghunaimi, at 156.

55 Khadduri, 'The Islamic theory of international relations and its contemporary relevance', in, at 31 .

56 Javaid Rehman, Islamic state practices, international law and the threat from terrorism: a critique of the "clash of civilizations" in the new world order (Hart 2005), at 49.

57 Ahmed Zaki Yamani, 'Humanitarian international law in Islam: a general outlook', in Hisham M. Ramadan (ed), Understanding Islamic law: from classical to contemporary (Rowman \& Littlefield Publishers 2006), at 66. 
therein, or if the Muslims and their dhimmis $\left.{ }^{58}\right]$ can find no protection and their residence is not safe".59 This would happen when, for example Friday prayers and the Festivals, i.e. the IIs, are prevented to take place and consequently their religious freedom is being undermined. ${ }^{60}$ Of course, the full exercise of the five individual obligations of every Muslim have to be ensured as well, namely the recognition of one God, the prayers, the Ramadan, the payment of zakat, i.e. tax benefiting the needy, and the pilgrimage to the holy places. In anticipation of violations by non-Muslims towards Muslims living in their territory, the non-Muslim political instances which reject an invitation to embrace Islam or in second instance are reluctant to sign dhimmah agreements recognising their personal laws under Islamic sovereign rule, become a threat. Their people would be considered to be belligerents. ${ }^{61}$ Siyar accommodated these two nations, i.e. those of the Muslims and non-Muslims, at war and prescribes the laws of war to be respected in their encounters. ${ }^{62}$

Siyar would also provide an appropriate definition of dar al-Islam, as opposed to dar al-harb, in order for Islamic territories to be delimitated. There, Islamic rule would prevail or Muslim subjects and their dhimmis could have safe residence under non-Islamic sovereigns. Hanafis did not accept the latter situation and required full incorporation of Muslims subjects and their dhimmis in Islamic territory through conquest. Successful secession of a territory which used to belong to the dar-Islam, according to the jurist al-Shafi (d. 820), becomes dar al-harb. ${ }^{63}$ However, the jurist Abu Hanifa (d. 767) argues that such rebellion would remain part of the dar al-Islam "except when it is not separated from dar al-harb by a Muslim territory". ${ }^{64}$ For the purpose of protecting the territorial integrity of the abode of Islam, so-called "military

$5^{8}$ Those with whom Islamic authorities have concluded a treaty allowing them to continue to exercise their own religious practice in exchange for a taxation (poll tax), i.e. the jizya, guaranteeing their protection in case of war. See Abu Sulayman, at 28-9.

al-Ghunaimi, at 156; see also Adel Théodor Khoury, Toleranz im Islam (Kaiser; Grünewald 1980), at 105 .

6o Saghir Ahmad Khan \& Abdur Rahim, Islamic jurisprudence (Mansoor 1986), at 120; Abdur Rahim, The principles of Islamic jurisprudence, according to the Hanafi, Maliki, Shafi'i and Hanbali schools (Kitab Bhavan 1994), at 376; Khoury, at 104.

61 An-Na'im, at 148; Sheikh Wahbeh al-Zuhili, 'Islam and international law', (2005) 87 International Review of the Red Cross, 269, at 278; Abu Sulayman, at 19-20; Hashmi, in, at 207; Ameur Zemmali, Combattants et prisonniers de guerre en droit islamique et en droit international humanitaire (E. Pedone 1997), at 31.

62 Hassan, at 136.

63 al-Ghunaimi, at 155-58; see also An-Na'im, at 150.

64 al-Ghunaimi, at 158. 
jihad" mandates the collective obligation, i.e. levée en masse, or the individual struggle of every capable believer against non-Islamic threats. ${ }^{65}$ Evidently, anyone who prevents and opposes Muslims to flourish within their territory and outside as Muslim aliens, could be considered to be in a state of war, i.e. harb, and jihad could rectify this unjust situation. It could be done through al-fath, i.e. conquest, in order for righteousness to prevail and God's message to be conveyed to everybody. However, such occupation and its transfer of sovereignty to the dar al-Islam differ from a military invasion wanting to realise specific strategic objectives with no intention whatsoever to annex the dar al-harb. ${ }^{66}$ The Qur'an refers to this wrong-doing to be addressed in the latter case:

To those against whom war is made, permission is given (to fight), because they are wronged — and verily, Allah is most powerful for their aid. (Q22:39)

(They are) those who have been expelled from their homes in defiance of right,-_(for no cause) except that they say, "our Lord is Allah". Did not Allah check one set of people by means of another, there would surely have been pulled down monasteries, churches, synagogues, and mosques, in which the name of Allah is commemorated in abundant measure. Allah will certainly aid those who aid his (cause); for verily Allah is full of Strength, Exalted in Might, (able to enforce His Will). (Q22:40)

In order for these adversaries of Islam ${ }^{67}$ to be fought in an external jihad they would need to be based in the dar al-harb and have become non-Muslims through their behaviour if they were it before; ${ }^{68}$ whether they are Muslims, i.e. the rebels/disserters, or not, i.e. the polytheists, non-Muslims, and in particular the Peoples of the Book/Scriptuaries (Christians, Jews, Magians (Zorostrians), and Sabians), or not anymore, i.e. the apostates. However, in practice, rebels and apostates despite the apostates' denunciation of Islam and of (one of) its five individual obligations are technically still Muslims. A war waged against

65 Freamon, at 307; at 454; Hilmi M. Zawati, Is jihad a just war? War, peace, and human rights under Islamic and public international law (Edwin Mellen Press 2001), at 16.

66 Zawati, at $18-9$.

67 Nikolai Egorovich Tornau, Das moslemische Recht: aus den Quellen dargestellt (Rodopi 1970), at 51 .

68 al-Ghunaimi, at 138-39; Hashmi, in, at 205-6. 
rebels and apostates will be examined under internal warfare against enemies of Islam from within, although their treatment will not be that different from the external rivals of Islam. ${ }^{69}$

\subsubsection{Temporal Jurisdiction}

\subsection{The Opening of the War}

Declarations of war are necessary and in particular against the signatory party to a treaty which has threatened to violate its terms; except in the case of selfdefence against an attack regardless of the existing treaty relations with the aggressor or in the case of retaliation against an effective breach of treaty. ${ }^{70}$ The following verses in the Qur'an imply a reference to such a (possible) violation of a treaty by the enemy which would have to be denounced or even fought against:

If thou fearest treachery from any group, throw back (their covenant) to them, (so as to be) on equal terms: for Allah loveth not the treacherous. (Q8:58)

But if they violate their oaths after their covenant, and taunt you for your Faith,- - fight ye the chiefs of Unfaith: for their oaths are nothing to them: that thus they may be restrained. (Q9:12)

Will ye not fight people who violated their oaths, plotted to expel the Messenger, and took the aggressive by being the first (to assault) you? Do ye fear them? Nay, it is Allah Whom ye should more justly fear, if ye believe! (Q9:13)

Obviously, sympathetic and humanitarian assistance to those who seek help against injustice regardless whether they are Muslim or not and wars for idealistic reasons to spread Islam necessitate a declaration. ${ }^{71}$ In the case of humanitarian intervention the Qur'an provides that:

69 An-Na'im, at 150.

70 Hamidullah, at 191.

71 Hassan, at 171; Mahmassani, at 290; see also Matthias Vanhullebusch, 'Islamic law and the responsibility to protect', (2010) 4 Human Rights and International Legal Discourse, 191. 
And why should ye not fight in the cause of Allah and of those who, being weak, are ill-treated (and oppressed)?-Men, women, and children, whose cry is: "Our Lord! Rescue us from this town, whose people are oppressors; and raise for us from thee one who will protect; and raise for us from thee one who will help!" (Q4:75)

If any one slew a person-unless it be for murder or for spreading mischief in the land-it would be as if he slew the whole people: and if any one saved a life, it would be as if he saved the life of the whole people. $\left(Q_{5}: 32\right)$

However, wars cannot be fought during the sacred months, nor can they be started in this period, unless the very existence of the Islamic community is at stake. This ruling has been a reminiscent of pre-Islamic Arabian tribal society in order to, on the one hand, facilitate peace and let trade flourish, and on the other hand, grant time and resources to (re)organise for the battle afterwards. The Qur'an provides in that regard:

The prohibited month for the prohibited month,- -and so for all things prohibited,- - there is the law of equality. If then any one transgresses the prohibition against you, Transgress ye likewise against him. But fear Allah, and know that Allah is with those who restrain themselves. (Q2:194)

The number of months in the sight of Allah is twelve (in a year) - so ordained by Him the day He created the heavens and the earth; of them four are sacred: that is the straight usage. So wrong not yourselves therein, and fight the Pagans all together as they fight you all together. But know that Allah is with those who restrain themselves. (Q9:36)

They ask thee concerning fighting in the Prohibited Month. Say: "Fighting therein is a grave (offence); but graver is it in the sight of Allah to prevent access to the path of Allah, to deny Him, to prevent access to the Sacred Mosque, and drive out its members." Tumult and oppression are worse than slaughter. (Q2:217)

But when the forbidden months are past, then fight and slay the Pagans wherever ye find them, an seize them, beleaguer them, and lie in wait for them in every stratagem (of war); but if they repent, and establish regular prayers and practise regular charity, then open the way for them: for Allah is Oft-forgiving, Most Merciful. (Q9:5) 


\subsection{The End of the War}

The belligerent parties can simply cease the armed hostilities without agreeing upon the terms of a truce or an armistice. Of course, war can also be settled through treaties of peace respecting the respective sovereignties and independence of both parties. Thus, the former enemies enter into the abode of the covenant, envisaging some long-term peace. ${ }^{72}$ There is disagreement among jurists whether the treaty is only valid for ten years as was the case of the Hudaibiyah treaty (d. 628) signed by the Prophet or whether it can be renewed as any other contract. ${ }^{73}$ The Qur'an warns Muslims to remain vigilant whenever eternal friendship with non-Muslims has to be concluded:

Should they intend to deceive thee,- - verily Allah sufficeth thee: He it is that hath strengthened thee with His aid and with (the company of) the Believers. (Q8:62)

O ye who believe! Take not the Jews and the Christians for your friends and protectors: They are but friends and protectors to each other. And he amongst you that turns to them (for friendship) is of them. Verily Allah guideth not a people unjust. (Q5:51)

And those who believe will say: "Are these the men who swore their strongest oaths by Allah, that they were with you?" All that they do will be in vain, and they will fall into (nothing but) ruin. (Q5:53)

Whenever the non-Muslim enemy was defeated and its territory was annexed after all into the dar al-Islam, preference would be given to the ruler and its people who embraced Islam or accepted the suzerainty of the Islamic victor. In return they could continue to practice their own religion and personal laws. ${ }^{74}$ Once the persecution had ceased and freedom of religion could be fully professed, according to Ali, the "sword had to be sheathed".75 In this regard, the Qur'an reminds of God's omnipotence to unite peoples of different beliefs:

And (moreover) He hath put affection between their hearts: not if thou hadst spent all that is in the earth, couldst thou have produced that affection, but Allah hath done it: for He is Exalted in might, Wise. (Q8:63)

\footnotetext{
72 Hamidullah, at 266; al-Zuhili, at 278.

73 Hamidullah, at 267 .

74 Id., at 265-66; An-Na'im, at 148.

75 Ali, A manual of hadith, at 253 .
} 
It may be that Allah will grant love (and friendship) between you and those whom ye (now) hold as enemies. For Allah has power (over all things). And Allah is Oft-Forgiving, Most Merciful. (Q60:7)

\subsubsection{During Internal Warfare}

1.2.3.1 Territorial Jurisdiction

In principle, no wars could be fought within the dar al-Islam and obedience to the Islamic leadership had to be ensured. ${ }^{76}$ In reality, wars from within have been waged by the murtaddun, i.e. the apostates, by the muharibun, i.e. the bandits, brigands, highway robbery men, and by the bughah, i.e. the rebels. ${ }^{77}$ Generally, each of their behaviours is variably detrimental and subversive to the interests and values of the Islamic community. ${ }^{78}$ On the one hand, rebels challenge the righteous authority of the Islamic established authorities within the dar al-Islam..$^{79}$ On the other hand, apostates have renounced their Islamic faith or have refrained from observing one of their individual religious obligations and are therefore a threat which needs to be cured. Thus, apostasy wars were justified. ${ }^{80}$ Some verses in the Qur'an speak about those tensions within the ummah. For example:

Those who turn back as apostates after Guidance was clearly shown to them,- - the Evil One has instigated them and busied them up with false hopes. (Q47:25)

With respect to the bandits, they also operate within the abode of Islam but for the sake of personal and pecuniary benefits they terrorise the helpless population, and in particular travellers on highways across that territory. ${ }^{81}$ The Shi'i jurist Abu Jafar al-Tusi (d. 1067) however, believes that also other motives can drive the actions of bandits which can terrorise on land, for example in cities and deserts, or on sea. ${ }^{82}$ Muharaba, i.e. brigandage, has been regulated by the ahkam al-hiraba, i.e. the laws relating to the crime of bandits and brigands.

\footnotetext{
76 Zemmali, at 165 .

$77 \quad$ Abou El Fadl, at 32.

78 An-Na'im, at 150.

79 John Kelsay, 'Al-Shaybani and the Islamic law of war', (2003) 2 Journal of Military Ethics, 63 , at 67 .

$80 \quad$ Yamani, in, at 71 .

81 Abou El Fadl, at 205-6.

82 Id., at 220.
} 
Thus, Islamic criminal law is the applicable law and not ILW. However, divergence exists on the nature of this activity whether it truly corrupts the (territorial) integrity and sovereignty of the ummah or the Islamic faith. The hiraba verse does not necessarily provide more answers.

The punishment of those who wage war against Allah and His Messenger, and strive with might and main for mischief through the land is: execution, or crucifixion, or the cutting off of hands and feet from opposite sides, or exile from the land: that is their disgrace in this world, and a heavy punishment is theirs in the Hereafter. (Q5:33)

In the tenth and eleventh century, most of the Hanafi jurists considered rebellion as a $\sin .{ }^{83}$ In this respect, rebellion differed from the crime of banditry as these alleged rebels were waging a "war against Allah and His Messenger" 84 within the dar al-Islam. The Islamic establishment easily accused those who opposed their rule of causing fitnah i.e. disbelief ${ }^{85}$ which needed to be brought to an end as part of the maxim of "enjoining the good and forbidding the evil".86 The treatment of these Muslims fighting against the Islamic leadership for theological reasons instead of worldly ones, which are impermissible, ${ }^{87}$ falls under the ahkam al-bughat, i.e. the laws relating to rebels under an Islamic public order. ${ }^{88}$ Other jurists classified it under many branches of Islamic law, including under siyar and jihad.89 The Hanbali jurist Ibn Taymiyya (d. 13271328), however, dismisses the different regulations as to the permissiveness of rebellion and describes any fighting among Muslims as fitnah. According to him, rebellion should be forbidden irrespective of the reasons why they are fought; whether, on the one hand, to defend against unjust rulers and their illegal commands, i.e. the theological war, or, on the other hand, to overthrow those rulers in order to crown oneself to merely gain power, i.e. the political war. ${ }^{90}$ The Qur'an also refers to strives among Muslims:

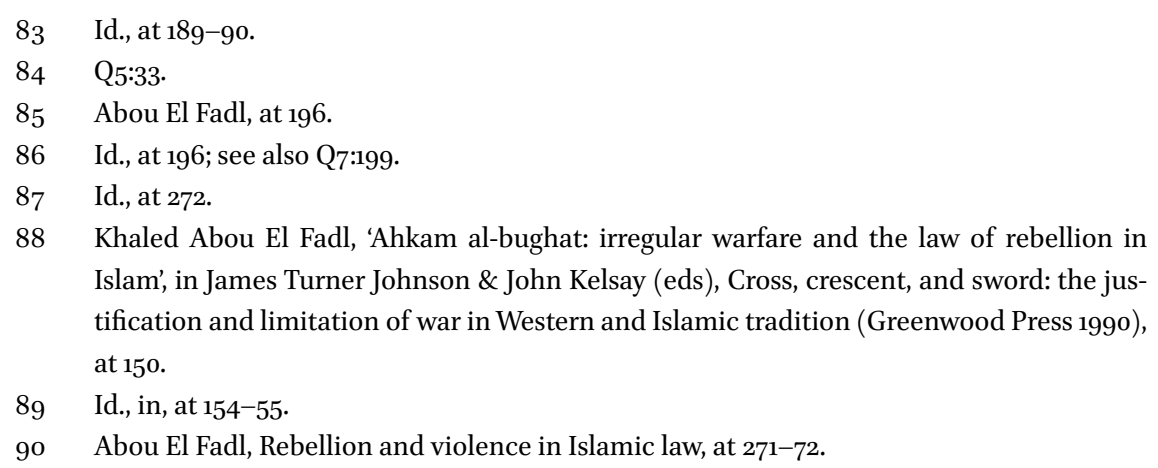


If two parties among the Believers fall into a quarrel, make ye peace between them: but if one of them transgresses beyond bounds against the other then fight ye (all) against the one that transgresses until it complies with the command of Allah; but if it complies then make peace between them with justice and be fair: for Allah loves those who are fair (and just). (Q49:9)

The Believers are but a single Brotherhood: so make peace and reconciliation between your two (contending) brothers; and fear Allah, that ye may receive Mercy. (Q49:10)

Generally, the jurists also supported reconciliatory means of dealing with the righteousness of conflicting and relative claims of the two groups. Despite the type of actions pursued by the rebels, punishments were discouraged.$^{91}$ Still, the Maliki judge Ibn 'Abd al-Barr (d. 1070) argues that terrorising for the propagation of their cause could disqualify rebels from their protective status and could be treated as common criminals instead. ${ }^{92}$ No matter in which territory the rebels are conducting their struggle against the Islamic leadership, they remain subjected to Islamic law having personal and thus universal jurisdiction over Muslims; whether they are in the dar al-Islam, the dar al-harb, the dar al-baghy, i.e. the abode of rebels enjoying partial recognition, or in the dar ahl $a l$-'adl, i.e. the abode of the loyalists claiming full legitimacy. ${ }^{93}$ However, nonMuslims who have effective control over territory within and who fight against the Islamic state, are treated as rebels under Islamic law; whereas Muslim rebels who border the dar al-harb and fight against the Islamic authorities, are supposed to be non-Muslims given the presumption of aid provided by their neighbours from the dar al-harb..$^{94}$

\subsubsection{Temporal Jurisdiction}

As for the beginning of war, similar rules of external jihad apply for internal jihad. In this regard, in terms of alleged disbelief, the apostates and rebels are also mushrikun. ${ }^{95}$ On the one hand, as for apostasy wars, converted Muslims

91 John Kelsay, 'Civil society and government in Islam', in Sohail H. Hashmi (ed), Islamic political ethics: civil society, pluralism, and conflict (Princeton University Press 2002), at 27; Abou El Fadl, Rebellion and violence in Islamic law, at 292 and 336.

92 Abou El Fadl, Rebellion and violence in Islamic law, at 222, 257 and 262.

93 Id., at $176-77$.

94 Hamidullah, at 185.

95 See Q9:36. 
who have signed any type of covenant which has ended a previous war between them (as non-Muslims) and the Islamic army and which has sanctioned their conversion to Islam, are liable from the moment they break this treaty and its obligations and risk retaliation. On the other hand, regarding rebellion, the Hanafi jurist Abu Bakr al-Sarakhsi (d. 1090-1091) adds that pre-emptive strikes are permissible by the loyalist Islamic army even before the rebels attacked the established Islamic authorities. Still, the commission of some overt acts on behalf of the rebels indicating their intent to rebel such as regrouping in particular locations can justify such pre-emptive action. ${ }^{96}$ Bandits, however, fall under the specific jurisdiction of the laws relating to brigandage.

\subsection{The Principle of Distinction}

\subsubsection{On Discrimination}

The Qur'an, the Sunnah and the practice of the successors of the Prophet Muhammad demand a strict adherence to the principle of distinction during armed hostilities. ${ }^{97}$ As a general rule Q2:190 "Fight in the cause of Allah those who fight you" makes this distinction clear. ${ }^{98}$ Such restriction on Islamic warfare in respect of permitted targets ${ }^{99}$ and the associated regimes of noncombatant immunities reveal functional caution ${ }^{100}$ to be exercised when dealing with non-combatants, i.e. those who are not (longer) participating in armed hostilities. This distinction and classification behind the enemies' lines can limit the number of atrocities of war as these persons cannot be attacked, killed or molested. ${ }^{101}$ The pre-Islamic rule of shahama, i.e. "man's boldness", 102 clearly has influenced and prohibited violent demonstrations of men's power against the weaker parties in societies under Islamic leadership. ${ }^{103}$ However, military necessity can override this protection for civilians and their property as allowed under the precept al-darura tubih al-mahzurat ("necessity makes

\footnotetext{
96 Abou El Fadl, Rebellion and violence in Islamic law, at 197.

97 Hashmi, in, at 211; see also Ella Landau-Tasseron, "Non-combatants" in Muslim legal thought, at http://www.futureofmuslimworld.com/research/pubID.6o/pub_detail.asp. (Last accessed 15 February 2015)

98 Shah, Islamic law and the law of armed conflict: the armed conflict in Pakistan, at 35 .

99 Tibi, in, at 180; Salem, at 121.

1 oo Johnson, The holy war idea in Western and Islamic traditions, at 119-20.

101 Zawati, at 43; Ali, A manual of hadith, at 253.

102 Tibi, in, at 181.

103 Id., in, at 181.
} 
the prohibited acts permissible"), ${ }^{104}$ whenever non-combatants are participating in the fighting, planning or supplying. ${ }^{105}$ Anyone who helps the enemy looses this protection ${ }^{106}$ and can be killed in self-defence or for reasons of belligerent reprisal. ${ }^{107}$ In case of wrong-doing against the Muslims, the Qur'an refers to reciprocity:

And so for all things prohibited,- - there is the law of equality. If then any one transgresses the prohibition against you, transgress ye likewise against him. But fear Allah, and know that Allah is with those who restrain themselves. (Q2:194)

The category of non-combatants ${ }^{108}$ include children younger than 15 years, women, slaves, old men, disabled and sick persons, both physically and mentally, because they would be incapable of bearing arms. ${ }^{109}$ Children until puberty could not yet have been infected by disbelief, i.e. as understood in terms of non-Muslim, apostasy or sinful rebellion, and consequently cannot be attacked. A hadith on the teachings of the Prophet and a command of Abu Bakr, the first caliph after the death of the Prophet, prescribe this very issue:110 "During some of the Ghazawat of the Prophet a woman was found killed. Allah's Apostle disapproved the killing of women and children."111 However, Abbasid jurists argue that women, children and old men may not be killed except when they die for a just cause leading to the victory of the Islamic state; for example in case they are commanders of, advisors to the army, or are rulers. ${ }^{112}$

Other civilians benefiting from immunities to be attacked are diplomats, merchants, and peasants given their important role as so-called "builders of prosperity"113 within the Muslim society and with its neighbours. ${ }^{114}$ Monks

\footnotetext{
104 Id., in, at 180.

105 Khadduri \& Liebesny, Law in the Middle East / Vol. 1, Origin and development of Islamic law, at 355; Hamidullah, at 223 .

106 Krüger, at 18. In particular the High Court of Lahore's decision: The State Bank of India Ltd. v. The Custodian of Evacuee Property, West Pakistan P.L.D. 1969, 1050.

107 al-Zuhili, at 282.

108 Hassan, at 173; al-Zuhili, at 277 and 280-81; An-Na'im, at 149.

109 Zawati, at 43; Johnson, The holy war idea in Western and Islamic traditions, at 119-20.

110 al-Zuhili, at 282.

111 Al-Bukhari, Vol. 4, Book 52, Number 257. (Narrated by 'Abdullah)

112 Hamidullah, at 223.

113 Yamani, in, at 82.

114 Zawati, at 44; Numan ibn Muhammad Ibn Hayyun, Ismail Kurbanhusien Poonawala \& Asaf Ali Asghar Fyzee, The pillars of Islam: Da'a'Im al-Islam of al-Qadi al-Nu'man (Oxford University Press 2002), at 453 .
} 
and hermits living in religious or spiritual isolation cannot be attacked either upon the condition that they do not take part in combat and remain in their churches, monasteries or cells. ${ }^{115}$ In this respect, places of worship are immune from attack. So are combatants who are no longer fighting because they are wounded or sick and thus are no longer participating in combat. None of these persons can be used as human shields when captured or taken hostage. ${ }^{116}$

This general principle of distinction is accused by Abdul Hamid Ahmad Abu Sulayman of lacking appreciation for the changing circumstances and modernisation of warfare, ${ }^{117}$ such as air strikes which are nowadays regulated by international conventions and have become part of Islamic law in the respective signatory states. ${ }^{118}$ Irrespective of the indiscriminate nature of modern weaponry, distinction shall guide the choice of targets as a first test during military operations. Unless military necessity mandates otherwise, the latter action requires the respect of the principle of proportionality, as a second test, in order to avoid unnecessary suffering to be inflicted upon any of the victims of armed attacks regardless whether they are combatants or not. Perfidious and treacherous actions blurring the distinction between lawful participants in combat are forbidden as well ${ }^{119}$ and are to be distinguished from ruses of war, such as surprise attacks, infiltration among enemy lines, spreading rumours among the latter, etc. ${ }^{120}$

\subsubsection{In External Warfare}

The principle of distinction is applicable in any armed conflict regardless whether the war is waged among believers or against unbelievers. Noncombatants on the one hand, cannot be the objects of attack; they deserve protection. ${ }^{121}$ When these non-combatants have suffered damages, the Muslim combatants can only be held responsible and liable under their laws of war when having intentionally ignored discriminate action on the battlefield. Hence, Muslim fighters are accountable for acts surpassing their belligerency. ${ }^{122}$ Others try to avoid any liability on behalf of the Islamic soldiers and accuse the leaders of the dar al-harb for having implicated their innocent population in

\footnotetext{
115 Zawati, at 43; Hamidullah, at 204; Yamani, in, at 82.

116 Hamidullah, at 206; David Aaron Schwartz, 'International terrorism and Islamic law', (1991) 29 Columbia Journal of Transnational Law, 629, at 649.

117 Abu Sulayman, at 77.

118 Hamidullah, at 229.

119 Id., at 204.

120 Yamani, in, at 76.

121 Freamon, at $323-24$.

122 Hamidullah, at 202-3.
} 
this struggle. ${ }^{123}$ The jurist al-Shafi in particular, continues that all of them can be killed because of their state of disbelief regardless of the Prophet's injunction to save their lives. ${ }^{124}$ In addition, both on land or at sea, Islamic warriors can attack respectively the castles or ships of their enemies even when they are shielded with Muslim subjects; thus, military necessity prevails. ${ }^{125}$

Muslim combatants on the other hand, should distinguish themselves from non-combatants. Even at the Prophet's time and in particular at one of the early battles, namely the Battle of Badr (d. 624), conducted for the defence of the ummah against the unbelievers, Muslim warriors were urged to wear distinctive signs or uniforms, such as woollen cloaks. Not only for the sake of telling them apart from their adversaries but also to receive the help of angels standing on their side. Cries of specific watchwords would facilitate the discrimination between friends from foes during campaigns at night. ${ }^{126}$

\subsubsection{In Internal Warfare}

With regard to the apostasy wars, only those who truly renounce the Islamic faith, whether they are men or women, can be the objects of targeting as only they are a threat to the stability and order of the Islamic community. Given the lack of supporting evidence, disagreement exists as to whether apostates should be executed or not unless they are remorseful for their actions of disbelief. ${ }^{127}$ Enslavement of apostates and confiscation of their property are not possible. ${ }^{128}$ The following verses in the Qur'an refer to open disbelief and hypocrisy:

The Hypocrites, men and women, (have an understanding) with each other: they enjoin evil, and forbid what is just, and are close with their hands. They have forgotten Allah. So He hath forgotten them. Verily the Hypocrites are rebellious and perverse. (Q9:67)

123 John Kelsay, 'Islam and the distinction between combatants and noncombatants', in James Turner Johnson \& John Kelsay (eds), Cross, crescent, and sword: the justification and limitation of war in Western and Islamic tradition (Greenwood Press 1990), at 205.

124 Abu Sulayman, at 12.

125 Khadduri, War and peace in the law of Islam, at 114.

126 Hamidullah, at 235; Lodewijk William Christiaan Van den Berg, Principes du droit musulman (A. Jourdan 1896), at 227 .

127 Abou El Fadl, Rebellion and violence in Islamic law, at 32.

128 Yamani, in, at 71. 
Those who break Allah's Covenant after it is ratified, and who sunder what Allah has ordered to be joined, and do mischief on earth: these cause loss (only) to themselves. (Q2:27)

Fight them, and Allah will punish them by your hands, cover them with shame, help you (to victory) over them, heal the breasts of Believers. (Q9:14)

The terrorisation of the population by bandits is not necessarily that different from the actions of a group of rebels which have a ta'wil, i.e. a cause, a justification for rebellion based on religious grounds, and who are, according to Tabassum, "striving to replace the existing illegitimate and unjust system with a legitimate and just order". ${ }^{29}$ The rebels located in a distinct territory over which they have effective control, ${ }^{130}$ can violate the rules of the Islamic regime through their acts of rebellion. ${ }^{131}$ The bandits, however, are prosecuted under criminal law. The rebels were rather treated at the discretion of the Islamic authorities assessing the legitimacy of their ideological claims ${ }^{132}$ for the purpose of justifying the use of force on their behalf. ${ }^{133}$ Depending on the qualification of the rebellion as being sinful or not, i.e. advocating disbelief or not, killing would be respectively permitted or prohibited. ${ }^{134}$ Rebels could also be killed whenever they sought refuge in their stronghold and were preparing for consecutive combats against the central Islamic authority. ${ }^{135}$

Generally, rebels could only be fought and killed as long as they disturb the peace and violate the loyalists' laws of order; restoring this does not imply their extermination. ${ }^{136}$ Whenever they were not able to fight through illness, injury, capitulation or capture, according to the jurist al-Shafi and the Shafi judge al-Mawardi (d. 1058), they would enjoy non-combatant immunity and were no longer objects of military targeting. ${ }^{137}$ Nonetheless, those supporting

129 Sadia Tabassum, 'Combatants, not bandits: the status of rebels in Islamic law', (2011) 93 International Review of the Red Cross 121, at 126.

130 Abou El Fadl, Rebellion and violence in Islamic law, at 168.

131 Kelsay, 'Civil society and government in Islam', in, at 26; Abou El Fadl, Rebellion and violence in Islamic law, at 150 .

132 Abou El Fadl, Rebellion and violence in Islamic law, at 202.

133 Abou El Fadl, 'Ahkam al-bughat: irregular warfare and the law of rebellion in Islam', in, at 163.

134 Abou El Fadl, Rebellion and violence in Islamic law, at 32.

135 Hamidullah, at 178; Abou El Fadl, Rebellion and violence in Islamic law, at 243.

136 Hamidullah, at 178; Abou El Fadl, Rebellion and violence in Islamic law, at 243.

137 Abou El Fadl, Rebellion and violence in Islamic law, at 150, $15^{2}$ and 171. 
the rebels or standing idly by can be considered as being as guilty and become legitimate objects of attack. Respect for the principle of distinction might just become subject to ideological concerns. ${ }^{138}$ As a response, insurgency or asymmetrical warfare tends to employ irregular tactics denying protection to noncombatants for the sake of winning the minds of the peoples to turn against the Islamic government. ${ }^{139}$

\subsection{The Principle of Proportionality}

\subsubsection{On Means and Methods of War}

The use of particular weaponry or military tactics which cause unnecessary suffering or bloodshed have to be limited in order to reduce the cruelties of warfare. ${ }^{140}$ The battles fought to preserve and to universalise the Islamic faith cannot ignore the humanity which Islam truly stands for and invoke (military) necessity to circumvent its basic principles of protection. ${ }^{141}$ Thus, the principle of necessity earlier referred to is curtailed by the precept al-darurat tuqdaru $b i$ qadariha ("necessity would be limited by proportionality"). Instead of expanding on those rules on the use of force during armed hostilities (jus in bello), the jurists have rather prioritised the development of the doctrine on the right to go to war (jus ad bellum). ${ }^{142}$ However, the regulation and restriction of human behaviour in order to fully develop in harmony within society and beyond, is the essence of the Qur'anic teachings. In this respect, any turbulence needs to be denounced regardless whether it takes place in peace or in war times. ${ }^{143}$ The Qur'an teaches on the limits to be respected in armed struggles:

138 Kelsay, 'Islam and the distinction between combatants and noncombatants', in, at 208.

139 Khaled Abou El Fadl, 'Ahkam al-bughat: irregular warfare and the law of rebellion in Islam', in see id., at 163 .

140 Hamidullah, at 225; Yamani, in, at 72.

141 Khadduri, War and peace in the law of Islam, at 102; Krüger, at 18 and in particular the High Court of Lahore's decision: The State Bank of India Ltd. v. The Custodian of Evacuee Property, West Pakistan, High Court of Lahore, P.L.D. 1969, 1050.

142 Christopher Gregory Weeramantry, Islamic jurisprudence: an international perspective (Macmillan 1988), at 138; Charles E. Butterworth, 'Al-Fârâbî's statecraft: war and the wellordered regime', in James Turner Johnson \& John Kelsay (eds), Cross, crescent, and sword: the justification and limitation of war in Western and Islamic tradition (Greenwood Press 1990), at 80 .

143 Falahi, at 88; al-Zuhili, at 282. 
And if ye do catch them out, catch them out no worse than they catch you out: but if ye show patience, that is indeed the best (course) for those who are patient. (Q16:126)

Fight in the cause of Allah those who fight you, but do not transgress limits; for Allah loveth not transgressors. (Q2:190)

Mutilation and torture of the enemy and its animals with eventually death as a result are forbidden. ${ }^{144}$ As a hadith prescribes: "The Prophet [...] forbade mutilation (or maiming) of bodies."145 In addition, "unnecessary devastation, destruction of harvest", 146 as Hamidullah lists, as well as the cutting of trees during the hostilities or the commission of massacres among the defeated are not contributing to the objectives set to win the war and thus they are prohibited acts. ${ }^{147}$ The Prophet Muhammad and the consecutive caliphs also commanded these injunctions to their Islamic armies. It was excluded that the destruction or extermination of the enemy could ever be a goal to be pursued in particular when there is enough good reason that this would not contribute to the victory of the Islamic armies. ${ }^{148}$ These policies do not only reflect humanitarian and moral considerations but are also driven by functional motivations; ${ }^{149}$ the potential values of captured enemies and their properties would serve the Islamic community unless the ummah would benefit from their annihilation; and this in spite of the verses on belligerent reprisals in the Qur'an. ${ }^{150}$ Therefore, the use of certain weaponry, such as so-called "poisonous arrows"151 and fire, which belong to the prerogatives of God only, ${ }^{152}$ were outlawed whereas others, such as smoke or gases, were permitted by some; however, "poisonous arrows" were permitted by others too, depending on

\footnotetext{
144 Hamidullah, at 204; Hassan, at 173; Peters, Jihad in classical and modern Islam, at 37.

145 Al-Bukhari, Vol. 3, Book 43, Number 654. (Narrated by 'Abdullah bin Yazid Al-Ansari)

146 Hamidullah, at 205 .

147 Hassan, at 173 .

148 Hallaq, Shari'a: theory, practice, transformations, at 329.

149 See Khaled Abou El Fadl, 'Between functionalism and morality: the juristic debates on the conduct of war', in Jonathan E. Brockopp (ed), Islamic ethics of life: abortion, war, and euthanasia (University of South Carolina Press 2003).

150 Johnson, The holy war idea in Western and Islamic traditions, at 122-24; Khadduri, War and peace in the law of Islam, at 107; for example Q2:194 and Q16:126.

$15^{1}$ Hamidullah, at 207; Hassan, at 173 .

152 Salem, at 123.
} 
the circumstances. ${ }^{153}$ Surprise attacks were encouraged as well because they would facilitate victory and reduce bloodshed. ${ }^{154}$

With regard to the captives made during the armed hostilities, the same prohibitions apply to these individuals. Thus, they cannot be killed, decapitated, nor burned and should be treated with human dignity and without unnecessary suffering. ${ }^{155}$ Rape of women in detention is considered as an act of adultery or fornication and Muslim combatants would be liable for such action under Islamic criminal law. ${ }^{156}$ In addition, public curiosity upon the dead bodies of the enemy is disliked. ${ }^{157}$ These instructions reveal significant progress made compared to the pre-Islamic custom of lex talionis, i.e. retaliation. ${ }^{158}$ Violators of these rules will be severely prosecuted under Islamic law. The Qur'an mentions how to treat captives:

Therefore, when ye meet the Unbelievers (in fight), smite at their necks; at length, when ye have thoroughly subdued them, bind a bond firmly (on them): thereafter (is the time for) either generosity or ransom: until the war lays down its burdens. $\left(Q_{47: 4)}\right.$

And they feed, for the love of Allah, the indigent, the orphan, and the captive. $\left(\mathrm{Q}_{7} 6: 8\right)$

Suicide attacks in particular raise greater concerns in terms of their legitimacy 159 in situations of asymmetrical armed conflict where this method of war, i.e. martyrdom, has mobilised many jihadists. ${ }^{160}$ According to some, fighting for the cause of God would justify any method of warfare against an impenetrable military adversary. Others would disagree and uphold the prohibition of acts of suicide in any event. ${ }^{161}$ The Islamic combatant has the intention to take away

153 Hamidullah, at 226.

154 Id., at 225 .

155 Zemmali, at 450; Mohamed M. El Zeidy \& Ray Murphy, 'Islamic law on prisoners of war and its relationships with international humanitarian law', (2004) 14 Italian Yearbook of International Law, 53, at 62.

156 Hamidullah, at 204-6; Hassan, at 173.

157 Mawardi \& Yate, at 80.

$15^{8}$ Hamidullah, at 315 .

159 Abou El Fadl, 'Ahkam al-bughat: irregular warfare and the law of rebellion in Islam', in, at 163 .

160 Freamon, at 302.

161 Ali K. Khan, A theory of international terrorism: understanding Islamic militancy (Martinus Nijhoff Publishers 2006), at 200-1; Muhammed Munir, 'Suicide attacks and Islamic law', (2008) 90 International Review of the Red Cross, 71, at 79. 
his or her own life ${ }^{162}$ and generally commits perfidy by not distinguishing himor herself from non-combatants. These actions usually ignore any principles of distinction or proportionality and deviate from the values supported by the ummah. ${ }^{163}$ Only God has the sole authority to create life and destroy it; $\mathrm{He}$ shall only award those who die in His cause and punish these sinful martyrs who fought for it. ${ }^{164}$ Generally, treacherous acts of warfare and mutilation are forbidden but can be permitted during reprisal actions. ${ }^{165}$ The Qur'an further elaborates on those being killed in action:

Fighting is prescribed for you, and ye dislike it. But it is possible that ye dislike a thing which is good for you, and that ye love a thing which is bad for you. But Allah knoweth, and ye know not. (Q2:216)

And if ye are slain, or die, in the way of Allah, forgiveness and mercy from Allah are far better than all they could amass. (Q3:157)

Let those fight in the cause of Allah Who sell the life of this world for the hereafter. To him who fighteth in the cause of Allah,- - whether he is slain or gets victory—Soon shall We give him a reward of great (value). (Q4:74)

And We should have shown them the Straight Way. (Q4:68)

Nor kill (or destroy) yourselves: for verily Allah hath been to you Most Merciful! (Q4:29)

If any do that in rancour and injustice, - - soon shall We cast them into the Fire: and easy it is for Allah. (Q4:30)

\subsubsection{During External Warfare}

When the unbelievers did not want to embrace Islam or pay jizya, i.e. the tax for dhimmis who live within the Islamic territory, in the first place, war was the last resort to subjugate them to Islam upon the condition of course that the Islamic armies were victorious. In this regard, the destruction of the

\footnotetext{
162 Freamon, at 308.

163 Tamara Sonn, 'Irregular warfare and terrorism in Islam: asking the right questions', in James Turner Johnson \& John Kelsay (eds), Cross, crescent, and sword: the justification and limitation of war in Western and Islamic tradition (Greenwood Press 1990), at 138.

164 Freamon, at 308; Franz Rosenthal, 'On suicide in Islam', (1946) 66 Journal of the American Oriental Society, 239, at 244.

165 Mahmassani, at 303 .
} 
unbelievers would be useless and would violate ILW. ${ }^{166}$ The general principle of proportionality for reasons of humanity and functionality are applicable as well. Nonetheless, sea jihadists can throw their captives and property into the sea, except if they are Muslims. ${ }^{167}$ However, the enemy combatants who are made prisoners of war and who deserve a kind treatment, ${ }^{168}$ can be (ab)used for political ends in order to undermine the morale of the adversary party. ${ }^{169}$ They could be executed when safe conduct could not be guaranteed. ${ }^{170}$ So, in accordance with the teachings of the Prophet, two prisoners of war at the Battle of Badr were decapitated because their trial proved that they committed crimes beyond their belligerency. ${ }^{171}$

\subsubsection{During Internal Warfare}

The use of certain weaponry, like flame-throwers, mangonels or other weapons of mass destruction, is not allowed in inter-Muslim strives unless military necessity requires so. ${ }^{172}$ This would be the case of first attacks on behalf of the rebels or when the loyalist armed forces are in the impossibility to defeat the rebels' stronghold upon the condition that innocent women and children not sharing the views of any of the parties to the conflict are not exposed to any risks. ${ }^{173}$ According to the Zahiri jurist Ibn Hazm (d. 1064), in case of the use of fire or flooding against the rebels, they must be evacuated safely in order to "escape death and surrender". ${ }^{174}$ Judge al-Mawardi continues that their homes cannot be burned nor flooded. ${ }^{175}$ Both Shafi and Hanafi jurists advocate a preferential treatment of captured rebels; they may not be killed even when rebels executed loyalists ${ }^{176}$ because the rebels would not be considered to be sinners. ${ }^{177}$ The rebels' moral claims are as relative to those of the Islamic authorities whose righteousness can only be appraised subjectively. ${ }^{178}$ In spite of being

\footnotetext{
166 Tibi, in, at 181.

167 Khadduri, War and peace in the law of Islam, at 115 .

168 al-Ghunaimi, at 148; al-Zuhili, at 283 .

169 Abu Sulayman, at 102.

170 Averroes, Imran Ahsan Khan Nyazee \& Muhammad Abdul-Rauf, The distinguished jurist's primer: a translation of Bidayat al-mujtahid (Garnet Publishing 1994), at 457.

171 Hamidullah, at 214; Weeramantry, at 135.

172 Abou El Fadl, Rebellion and violence in Islamic law, at 152 and 160.

173 Id., at 152, 216 and 259.

174 Id., at 216.

175 Id., at 172.

176 Id., at 173 and 194.

177 Id., at 175 .

178 Id., at 126.
} 
considered to be believers, Maliki jurists accept that the wounded rebels and fugitives may be killed unless the rebellion ends or its reinforcement stops. ${ }^{179}$ Needless to say, the power of rhetoric as retained by the jurists can as easily be manipulated to put any internal adversary to the Islamic regime outside the protection of ILW. As a consequence, rebels could have recourse to irregular means and methods of war instead.

\subsection{Conclusion}

Although the development of ILW and its application was intended to respect the universal message of Islam, on several occasions this message of peace has been interpreted differently given the specific circumstances of warfare at a particular time in the history of Islam. The introduction of the bipolar world as translated into the different jurisdictional regimes, i.e. the dar al-Islam and the dar al-harb, by the juristic community created an interpretation beyond the Revelation. Evidently, this theorisation further influenced the appreciation of the principles of distinction (between combatants and non-combatants) and of proportionality during armed hostilities to be applied therein. ILW has proven to be very sophisticated in its evolution and application during armed conflicts both against external or internal enemies of Islam. General principles of distinction and proportionality have become the object of juristic interpretation and are subject to communitarian and sovereignty propositions. The communitarian one advocates a more inclusive protection of the belligerent parties and non-combatants. The sovereignty position rather advances military necessity at the expense of the protection of the most vulnerable groups.

The structure of this Islamic legal argument is common to the secular national or international ones. This becomes clearer in Chapter II on IHL. Such positivistic dialogue between ILW and IHL may draw interesting conclusions in terms of recognition of their similarities. Although the degree of differences attributed by jurists across their borders accuses their antagonists, its outcome might mirror the non-observance of their own traditions against its own subjects and also toward its Others. Sufficient reasons can be given to understand this essentialist stance; in particular Part II will deal with this. Humanity, however, as will be pointed out in Part III, cannot afford to wait for these answers as each individual deserves to be protected from the cruelties and necessities of warfare. Therefore, even Chapter I's positivist account might advance the basic principles serving these ends to be applied accordingly, regardless of

179 Id., at 258 . 
the artificial divisions of humanity which were constructed in order to rule over it. Such inventions have contributed to the establishment and defence of Islamic empires and communities. However, the different abodes across which the universal message of Islam can be carried out have no textual support in the primary sources. Instead, the Qur'an is clear about the unity of humanity and about its diversity:

Mankind was one single nation, and Allah sent Messengers with glad tidings and warnings; and with them He sent the Book in truth, to judge between people in matters wherein they differed. (Q2:213)

O mankind! We created you from a single (pair) of a male and a female, and made you into nations and tribes, that ye may know each other (not that ye may despise (each other)). (Q49:13) 